\title{
Segmentation and Evidence of Relationship-Building Activities in Life Insurance Companies' Websites
}

\author{
Khalid Suidan Said Al Badi ${ }^{1}$ \\ ${ }^{1}$ Head of Internal Auditing Department, Al Buraimi College, Sultanate of Oman \\ Correspondence: Khalid Suidan Said Al Badi, Head of Internal Auditing Department, Al Buraimi College, \\ Sultanate of Oman. E-mail: k.vip.10@ hotmail.com
}

Received: August 6, 2014

Accepted: August 26, 2014

Online Published: September 25, 2014

doi:10.5539/ibr.v7n10p133

URL: http://dx.doi.org/10.5539/ibr.v7n10p133

\begin{abstract}
Companies that offer online insurance services have their work cut out for them. Not only must they search for loyal customers, but also for free advocates who can influence their friends to purchase an insurance policy online from them. In terms of time, cost and effort, attempting to attract the whole market is just a waste. As the best customer services with all insurance coverage for too much insurance policies is just vain. This is where the concept of target marketing comes in, as the most important factor influencing market share of an online insurance company is targeting an accurate market segment. Market segmentation is defined as a marketing strategy that involves dividing a broad target market into subsets of consumers who have common needs and priorities, and then designing and implementing strategies to target them. Market segmentation strategies may be used to identify the target customers, and provide supporting data for positioning to achieve a marketing plan objective. Businesses may develop product differentiation strategies, or an undifferentiated approach, involving specific products or product lines depending on the specific demand and attributes of the target segment (Kotler, 2003). Then again, it's not enough for a company to market its product to its customers. It has to keep and maintain that customer's loyalty through the provision of excellent services and other relationship-building activities. Our project aims to study these two aspects of online marketing by analysing the websites of three well-known insurance companies (www.metlife.com (US) www.standardlife.co.uk (UK), www.william-russell.com (UK). This paper will study the websites of the three selected insurance companies, which use similar E-Business models but different market segmentation, and examine how they intend to meet the needs of the different customer segments, and the extent to which they have managed to build customer relationship activities to maintain customer satisfaction through their website designs. Thus the study deals with these issues, not only from a customer perspective, but also from a business perspective. The findings present the effectiveness of the MetLife site which has offered various features to woo the retirement sector, whereas Standard Life has concentrated on the corporate client with regard to healthcare. William Russell is particularly focused on the expatriate client and is equally savvy for policy holders as it is with new customers.
\end{abstract}

Keywords: life insurance, E-business, marketing, segmentation, relation-building

\section{Literature of E-Business}

As the internet continues to transform the business world, businesses, along with their conventional systems of trading, try to reach out in order to cater for the needs of a large customer base in the comfort of their own homes. Electronic commerce companies have replaced one of the traditional marketing 4Ps - "place"- with "perception" that depends on the design of the company website. Several researchers have noted that adoption of internet-based business has become imperative for today's organisations in order to create value by cutting costs, attracting visitors and satisfying customers' needs by providing just-in time outcomes (Barsauskas et al., 2008; Soliman \& Youssef, 2003). The insurance business is no different. Gone are the days of long waiting hours in an office, a barrage of insurance jargon, and traps in the form of hidden costs, as all that the customer requires now is only a mouse-click away. Hence, the design of the company website plays a major role in creating customer loyalty and determining visitors' decision to stay, change to another electronic commerce site or return to their traditional market (Merwe \& Bekker, 2003).

Obviously, well-designed, effective and efficient website content attracts visitors to the company website, and convinces them to become a customer of the online business (Aladwani, 2006). 
According to E-business models presented by Chaffy (2007), insurance companies can be fitted into one of two models - the "revenue" and the "commercial" models.

A "revenue model" centres on value appropriation. Revenues can be realized through a combination of subscription fees, advertising fees and transactions.

$>$ The "commercial model" can be seen as brokerage and negotiator deals which can also be seen on these websites.

1. Marketplace position

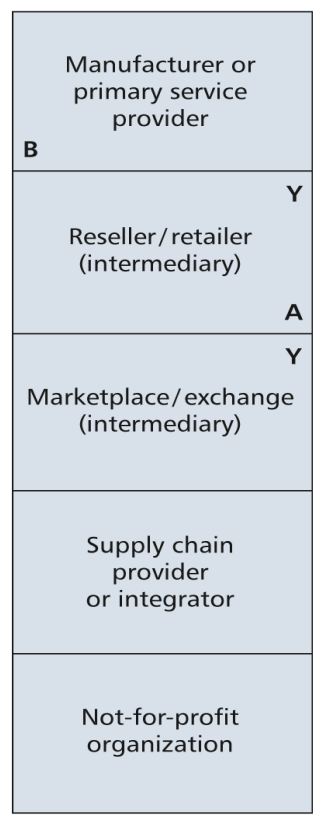

2. Revenue model

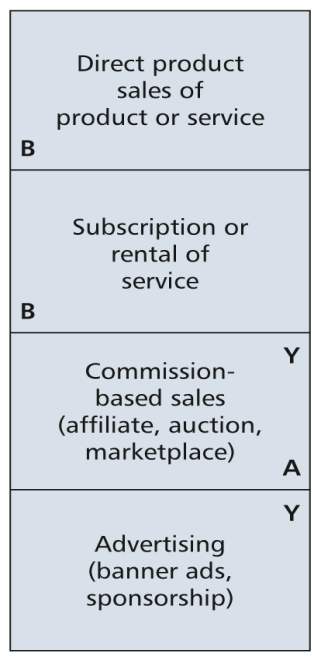

3. Commercial model

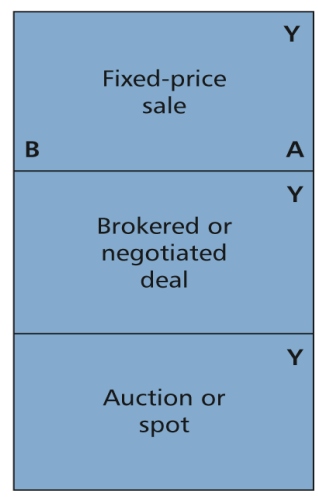

Key

$\mathbf{Y}=$ Yahoo!

$\mathbf{A}=$ Amazon

B $=$ Book publisher

Figure 1. Alternative perspectives on business models (Chaffy, 2007, p. 63)

This can be applicable for insurance companies. Models $2 \& 3$.

As far as dealing with target segmentation is concerned, one must understand that directing time, cost and effort at wrong target market is just a waste. Companies classify users into categories by use of free insurance quotes - into either price conscious, quality conscious or status conscious persons for online insurance policies. Target segments are chosen demographically, geographically and psycho-graphically or behaviourally for online insurance companies whether in the USA, the UK or elsewhere.

\section{Methodology}

This paper prepared evaluation criteria for the three websites (www.metlife.com, www.standardlife.co.uk and www.william-russell.com) based on the literature. It shall discusses how these companies focus on their target segments demographically, geographically and psychographic, customer-wise and product-wise. The findings have also studied the features present in each site to encourage relationship-building activities to attract and maintain customer loyalty. For this analysis, the paper has approached the websites as an ordinary user.

\section{Who Are the Websites Targeting?}

The companies are well known for their services. They are multinational in nature. Two are based in the UK, and one in the USA. Each one has made it clear that it is targeting one segment rather than any other segment. Target segments range from individuals, to corporate clients, to brokers, to intermediaries and to expatriates. The segments also vary in terms of the type of services and products offered. For example, MetLife targets retirement customers, Standard Life targets corporate business, and William Russell targets expatriates living outside their native countries.

\section{Evaluation Criteria}

Before start the website analysis we shall discuss some of the basic evaluation criteria to be used in the form of a checklist. Since our evaluation will be solely concentrating on the extent of segmentation to attract different 
customer groups, and specific features in site for relationship-building activities. We shall modify Knox's (2007) list to include these features. The checklist is very focused on first impressions from a business point of view. If users do not like a site, for whatever reason, they just leave. If they do stay, we have to consider what webpage features can help and encourage them to complete an insurance transaction.

1) Is the company name and logo on every page? Does it suggest brand and status?

2) Does the site's free insurance quotes allow price conscious users to compare them with others online, and does the user understand the aim is to categorise him into the proper user list?

3) Is segmentation done customer-wise, product-wise, demographically, geographically, psycho-graphically and is it based on benefits?

4) Are headlines and page titles clear?

5) Do links work and clearly describe the page they will lead to?

6) Are there benefits for switching or bringing in others, creating behaviour segments?

7) Can you leave feedback or extend the relationship, e.g. through a newsletter.

\section{Website Analysis Site No-1-Metlife (www.metlife.com)}

At first sight, the home page is very pleasant, with a vibrant feel, and a nice warm picture. The page is not crowded, and allows easy navigation. There is the company logo on every page so that the user will be aware if he clicks away from the site. The homepage consists of clear headlines and titles, making it easy to choose from as the browser wishes.

\subsection{Segmentation Focus of MetLife}

a). Product-wise retirement schemes

MetLife has made it clear that it targets baby boomers of the 1960s in the Retirement, and health, accident and life insurance section for customers from some countries in America, Asia and Europe. They have put in a lot of effort to present this information in a very simple and understandable manner, even for novices. They have explained all the stages in the cycle in a stepwise manner that can educate users and allow them to simply follow the steps.

There are also several linkages to schemes and IRA benefits. For example, in the investment link, three pages deal with deferred and income annuities, IRA's and Immediate annuities, and explain how to enrol in the retirement scheme. One can also access the income annuity guide to understand its benefits in retirement.

There are various tools to calculate how much you need to save, premiums, interest compounding, etc., including how this is actually calculated, and which type of insurance would actually suit one. Alternatively, one can also get a quote according to one's financial position.

b) Customer-wise

Individuals, businesses, brokers and consultants.

c) Geographically

It has operated for a long time in the City of New York, gathering clients from a variety of businesses with different types of insurance - auto, estate, health, etc.

d) Demographically

Americas (6-countries) - Asia (7-countries) - Europe (3-countries) with three languages used on the web interface. e) Behaviourally

Customers are invited to ask for a quote and to receive information through the site as a result of trust built up over years of business.

f) Psychographic

Matching needs to lifestyles in the way they provide a service.

\subsection{Relationship Building Activities of Metlife}

Website has shown a close relationship according to events such as National events, New Year's Eve to keep personal contact with clients. One can also follow events at MetLife posted on the Press Releases link. Feedback options are available from customer on line enquiries to comment cards that evaluate customer satisfaction with services. You have options for a representative to contact us and also to find offices close to us for details and enquiry. Also ease of procedure to change address/ contact numbers online itself. 


\section{Website No-2-Standard Life (www.standardlife.com)}

The company is based in the UK and provides a multitude of services.

This website is a no-frills one which gets down directly to business. The Standard Life logo is on every page. However the pages are white and the fonts is too small and the pages have no borders.

\subsection{Segmentation Focus of Standard Life}

a) Product wise

Insurance Healthcare for corporate clients. Ease of procedure and explanations aim to woo corporate clients to the site. The plan covers not only health but dental and travel insurance, with preventive modules also available.

The site also provides a step-by-step guide for making a business health plan which is easy to follow. Companies also have the option to contact the Standard Life health adviser.

The website provides example plans and tailor-made plans according to one's budget.

Standard Life has an aggressive strategy to woo clients by providing discount options once employee cover has been selected, reducing premium levels without affecting total cover. For corporate clients who wish to switch to Standard Life there is the option to continue with the same benefits or the same underwriting agreement and different benefits.

Corporate healthcare with extra benefits is given when 100+employees are covered.

b) Geographically

It has operated for a long time in the UK, gathering clients from a variety of businesses.

c) Demographically

Corporate clients.

d) Benefits

Discounts and switching benefits provided.

\subsection{Relationship-Building Activities of Standard Life}

The company takes its customer relationships very seriously. There are direct linked sites for complaints and feedback which only clients with secured id's can use. Contact numbers are also available. The site also sends clients an Ethical Funds Newsletter in which results of various surveys and the comments of clients, are published. Surveys are also done on an annual basis.

\section{Website No-3-William RusseLL (www.william-russell.com)}

The company provides award-winning insurance services to its clients who are expatriates. These include corporate clients, individuals and families, and intermediaries. The home page reeks of ambience made out in cool white and blue. Below the page, one can find a site map that makes navigation through this site very easy. The home page basically divides clients into corporate clients, individuals and families, and intermediaries, providing Global Life, Global Health and Global Income options in each category. The William Russell logo is on every page. The logo appears to be a status brand.

\subsection{Segment Focus of William Russell}

a) Product wise

It provides Global Health, Global Life and Global Income protection.

Each category is simply and easily explained. There are contact numbers for its offices in Dubai, Malaysia and the UK. Call back options are available at the client's convenience.

Tailor-made solutions are available for individuals and corporate clients, Existing policy holders are linked to every page on the site to make complaints, renewals, claims, etc.

Quote options are available on every page for individuals and for groups, along with testimonials that add credibility to the site

Complementary-like discounts are available for recommending the company to a friend, platinum plans, etc. All these market strategies are aggressively and effectively brought out in the site.

b) Geographically

It is based in the UK, with offices in Dubai, Indonesia and London 
c) Demographically

Service are catered to all nationalities globally (expatriates)

d) Customer wise

Individuals, corporate, and intermediaries

e) Behaviourally

Platinum schemes available and brand name are strong psychological pullers.

\subsection{Relationship-Building Activities of William Russell}

The company appreciates feedback and publishes this on the site in the form of testimonials and case studies. Dissatisfied customers have the option to call the relevant Director and not just a simple customer service line.

\section{Website Analysis}

Table 1. General website analysis

\begin{tabular}{|c|c|c|c|}
\hline \multirow[b]{2}{*}{ Characteristics observed } & \multicolumn{3}{|c|}{ Company name and website address } \\
\hline & $\begin{array}{c}\text { Met Life } \\
\text { www.metLife.com } \\
\end{array}$ & $\begin{array}{c}\text { Standard Life } \\
\text { www.standardlife.co.uk } \\
\end{array}$ & $\begin{array}{c}\text { William Russell } \\
\text { www.william-russell.com } \\
\end{array}$ \\
\hline $\begin{array}{l}\text { Direct sales of services. } \\
\text { Commercial brokerage } \\
\text { and negotiated dealers }\end{array}$ & $\begin{array}{l}\text { Revenue and } \text { commercial* }^{*} \text { - } \\
\text { Uses agents also }\end{array}$ & Revenue & $\begin{array}{l}\text { Revenue and commercial } \\
\text {-encourages use of intermediaries }\end{array}$ \\
\hline Business strategy & $\begin{array}{l}\text { Targeting retirement, heath, life } \\
\text { and accident insurance sector } \\
\text { (Americas ( } 6 \text { countries) - Europe } \\
\text { ( } 3 \text { countries), Asia ( } 7 \text { countries) }\end{array}$ & $\begin{array}{l}\text { Targeting corporate sector in UK } \\
+ \text { some other countries }\end{array}$ & $\begin{array}{l}\text { Targeting expatriate sector outside } \\
\text { UK. }\end{array}$ \\
\hline Websites comment notes & $\begin{array}{l}\text { Good presentation, easy } \\
\text { navigation. Comprehensive. } \\
\text { Three different languages. }\end{array}$ & $\begin{array}{l}\text { Font is too small, colours too } \\
\text { drab to capture attention of user }\end{array}$ & $\begin{array}{l}\text { Good presentation but too little } \\
\text { information at the forefront }+ \\
\text { more pictures that delay access }\end{array}$ \\
\hline $\begin{array}{l}\text { Comments for affective } \mathrm{E} \\
\text { Business webpage }\end{array}$ & $\begin{array}{l}\text { More testimonials to add } \\
\text { credibility }\end{array}$ & $\begin{array}{l}\text { More attention to homepage to } \\
\text { make it warm and interesting }\end{array}$ & $\begin{array}{l}\text { Allow customers to register } \\
\text { on-line }\end{array}$ \\
\hline General Observation & Very good & Could use better presentation & Good \\
\hline
\end{tabular}

Table 2. Web site analysis, online target segmentation (Criteria 1)

\begin{tabular}{|c|c|c|c|}
\hline \multirow{3}{*}{$\begin{array}{l}\text { Target } \\
\text { Segmentation }\end{array}$} & \multicolumn{3}{|c|}{ Company name and website address } \\
\hline & Met Life & Met Life & Met Life \\
\hline & www.metLife.com & www.metLife.com & www.metLife.com \\
\hline Geographic & USA & UK & Global \\
\hline Demographic & Retirement sector & Healthcare & Health, Income, Life \\
\hline Product Focus & Retirement Schemes & Business and corporate healthcare & Global health, income, life schemes \\
\hline Customer wise & $\begin{array}{l}\text { Individuals, businesses, brokers } \\
\text { and consultants. }\end{array}$ & Corporate & $\begin{array}{l}\text { Individuals, corporate and } \\
\text { intermediaries }\end{array}$ \\
\hline Psychographic & Matching needs to lifestyle & Tailor-made healthcare schemes & Matching needs to lifestyle \\
\hline Benefits & Not known & Reduction in switching cost and discounts & $\begin{array}{l}\text { Discounts+ free travel with Platinum } \\
\text { Plan }\end{array}$ \\
\hline
\end{tabular}


Table 3. Website analysis, online target segmentation (Criteria 2) (Brand name, Price and Status Criteria)

\begin{tabular}{lccc}
\hline Rank: $\mathbf{1}=$ Dire & $\mathbf{1 0}=$ Excellent & & \\
\hline Target Segmentation & Met Life & Standard Life & William Russell \\
Brand Conscious & 8 & 8 & 8 \\
Price Conscious & 8 & 7 & 5 \\
Status Conscious & 7 & 5 & 8 \\
Total & $\mathbf{2 3}$ & $\mathbf{2 0}$ & $\mathbf{2 1}$ \\
\hline
\end{tabular}

Different customers think in different ways about their insurance requirements. However their main concerns are:

- Brand name of insurance company

- Price (Premium)

- Status

The analysis of the target segmentation is based on the type of customer orientation. This can be shown in Table 4 . If we give Rank $1=$ Dire and Rank $10=$ Excellent, the MetLife ranks highest while the other two have almost the same ranking.

Table 4. Analysis of website based on relationship activities

\begin{tabular}{llll}
\hline & Met Life & Standard Life & William Russell \\
\hline Type of relationship activities & Individual, & Comment cards, & Ethical funds surveys, newsletter, \\
& Business, & Press releases on site & feedback \\
& Focused Groups & feedback & \\
\hline
\end{tabular}

\section{Recommendations}

\subsection{Met Life}

Relationship-building activities need to be improved. It comes across as being too occasional and impersonal. Perhaps Testimonials from satisfied customers and annual newsletters would help in building relationships.

\subsection{Standard Life}

1) Although it targets the corporate sector, the range of online comprehensive insurance services is too narrow (only healthcare). If a client wants travel insurance, $\mathrm{s} /$ he has to subscribe to the whole package. Though this may be economical, it is not always convenient.

2) Although their relationship-building activities are adequate, it is strongly recommended that the include testimonials since proper testimonials can be of prime importance in establishing the credibility of any website.

3) Use of colors and larger fonts may also help in relationship-building by giving the website a more personal and friendly feel.

\subsection{William Russell}

1) They are targeting expatriates (anyone outside the UK) which is too broad a segment. Giving equal importance to all the online services provided by them may not be competitive. It would be wiser to stress one type of online insurance scheme.

2) Although they use testimonials for relationship-building activities, they could improve their relationship-building activities through the use of newsletters and online surveys.

3) Make provision for accepting customer complaints online.

\section{Conclusion}

Our analysis of these websites was done in the manner of a novice rather than an expert. As we evaluated these websites as visitors, over a very short period and with only access to the general content as users of the internet, our judgment lacked concrete analysis. Therefore, all the characteristics that we have analysed are those that can easily 
be accessed, rather than those that can be found from hours of browsing or being a real customer attempting to form a judgement. The websites were also assessed on their ease of use. On the basis of our findings, we have formed a table comparing and contrasting the three insurance companies. In the target segment category, we have graded Met Life better than the others since its targeting of the retirement sector is aggressive and clear through various linkages, advertisements and animated presentations. All of this is enough to make even a casual browser curious about their scheme's benefits. This, coupled with ease of use and a three language interface, make it undoubtedly the best site in this category. In the relationship-building category, Standard Life has the upper hand with expert handling of customer complaints and protection of customer interests. Surveys and annual newsletters further strengthens its lead position in this category.

\section{References}

Aladwani, A. M. (2006). An empirical test of the link between web site quality and forward enterprise integration with web consumers. Business Process Management Journal, 12(2), 178-190. http://dx.doi.org/10.1108/14637150610657521

Barsauskas, P., Sarapovas, T., \& Cvilikas, A. (2008). The evaluation of e-commerce impact on business efficiency. Baltic Journal of Management, 3(1), 71-91. http://dx.doi.org/10.1108/17465260810844275

Chaffey, D. (2007). E-Business and E-Commerce Management (3rd ed.). England: Prentice Hall.

Donio, J., Massari, P., \& Passiante, G. (2006). Customer satisfaction and loyalty in a digital environment: an empirical test. Journal of Consumer Marketing, 23(7), 445-457. http://dx.doi.org/10.1108/07363760610712993

Http://hbswk.hbs.edu/archive/2381.html

Http://knowledge. wharton.upenn.edu/article.cfm?articleid=254

Http://www.Metlife.com.

Http://www.Standardlife.com

Http://www.william-russell.com

Knox, I. (2007). Retrieved on 28th March 2009 from http://www.scribd.com/doc/20505/Web-page-review-tips

Merwe, R., \& Bekker, J. (2003). Framework and methodology for evaluating ecommerce website a framework and methodology for evaluating ecommerce website. Internet. Research: Electronic networking Application and policy, 13(5), 330-341. http://dx.doi.org/10.1108/10662240310501612

Philp, K. (2011). Marketing Management (7th ed.). International Prentice Hall

Stephen, W. S. (1997). Save the Time of Surfer: Evaluating websites for Users. Library High Tech, 15(3/4), 155-158. http://dx.doi.org/10.1108/07378839710308501

Soliman, F., \& Youssef, M. A. (2003). Internet based e-commerce and its impact on manufacturing and business operations. Industrial Management \& Data System, 108(3), 446-552. 


\section{Appendix}

\section{Appendix 1}

Home page of www.metlife.com

IRA's \& annuities

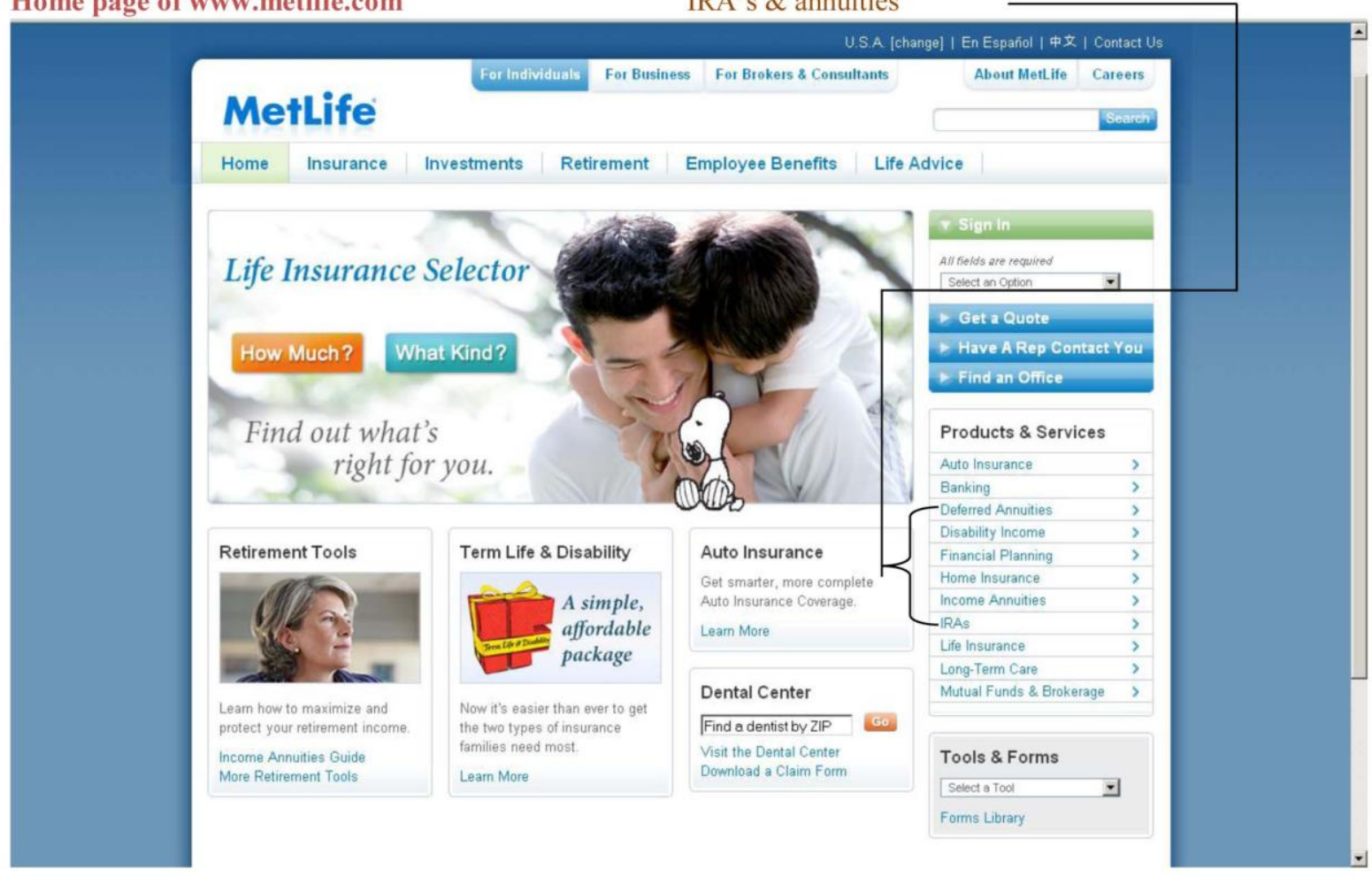

Appendix 2

Customer Segmentation MetLife- Retirement Scheme

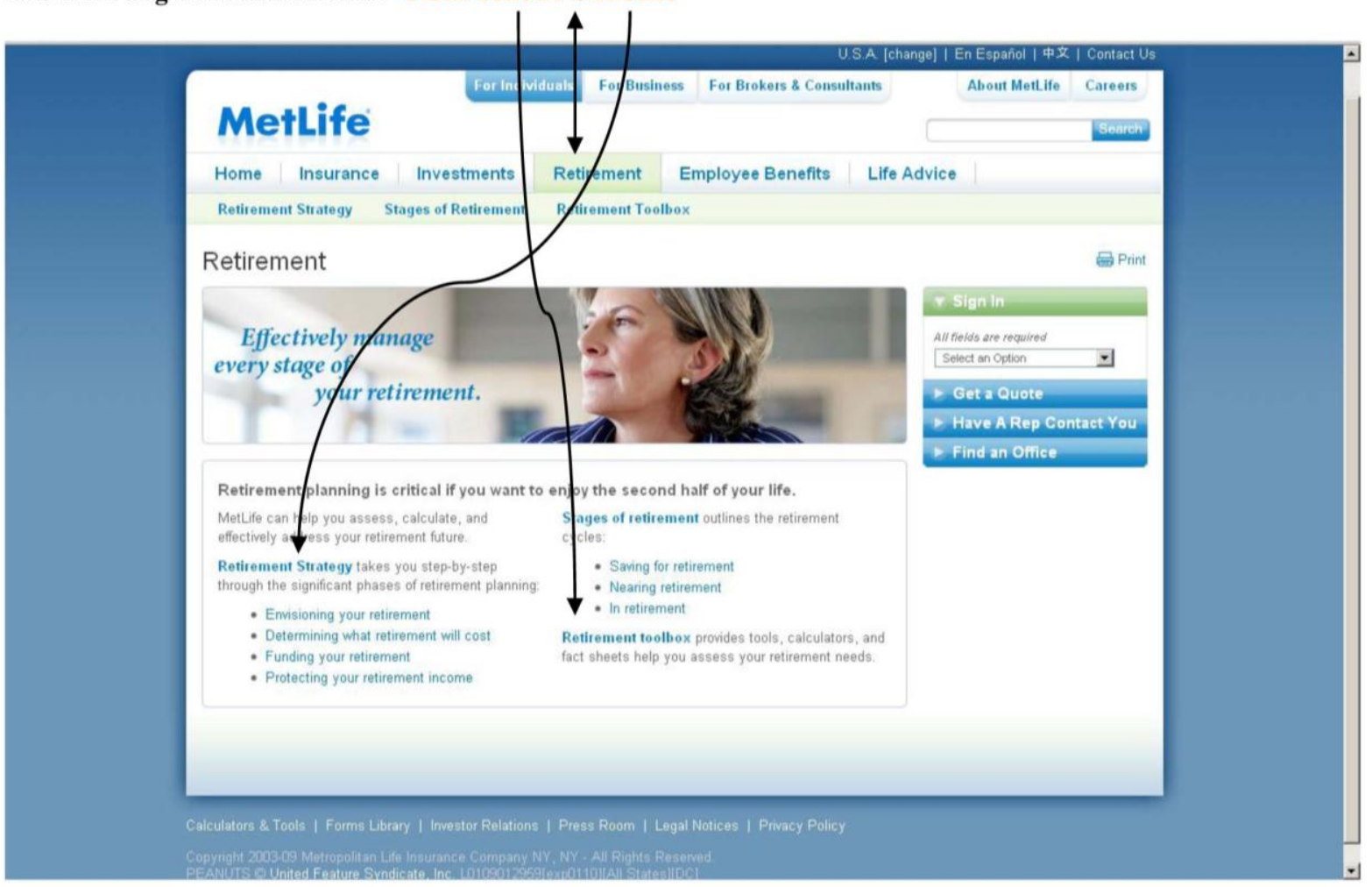


Appendix 3.

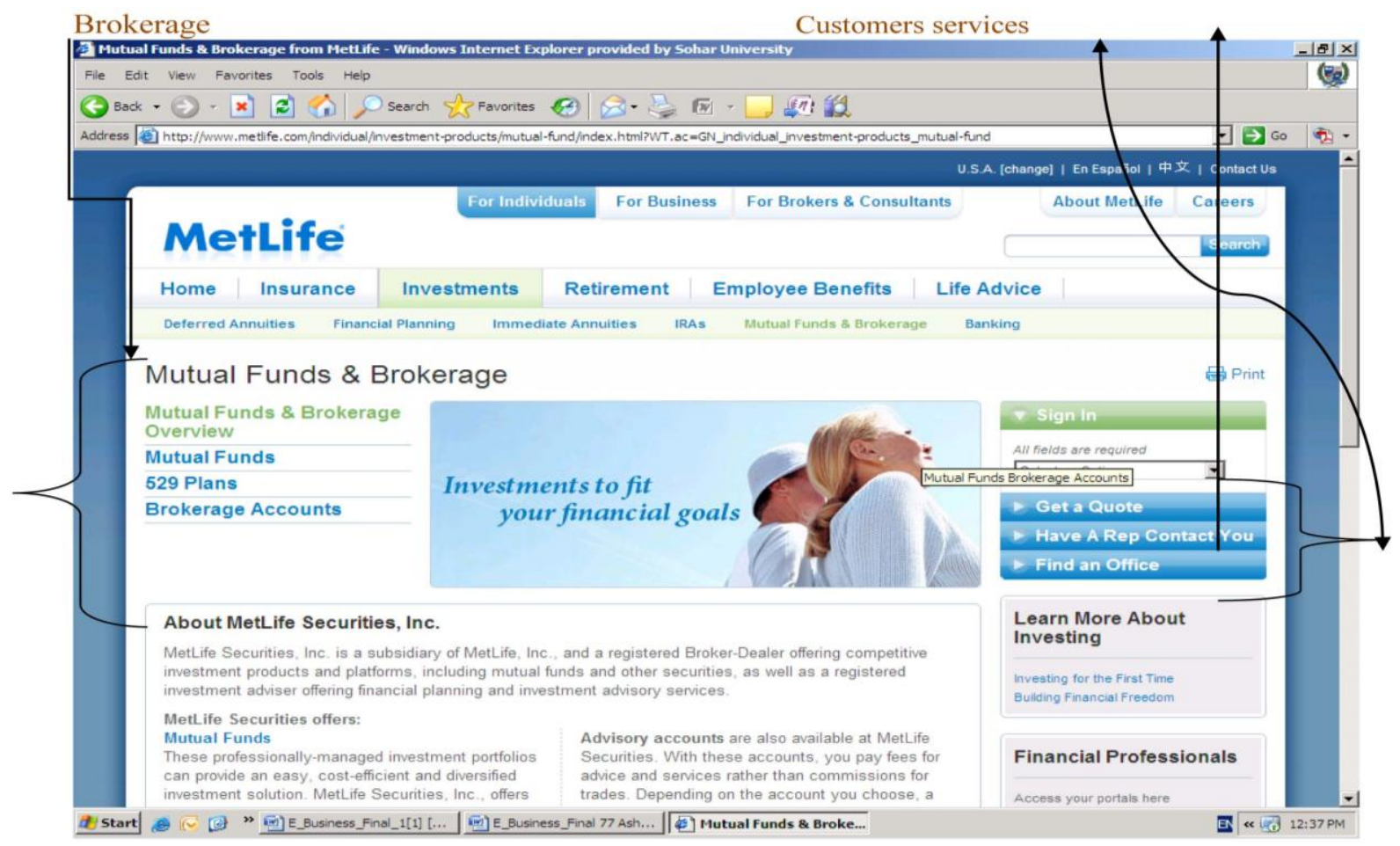

Appendix 4. Standard Life Home Page of UK

Customer Segmentation, - Healthcare

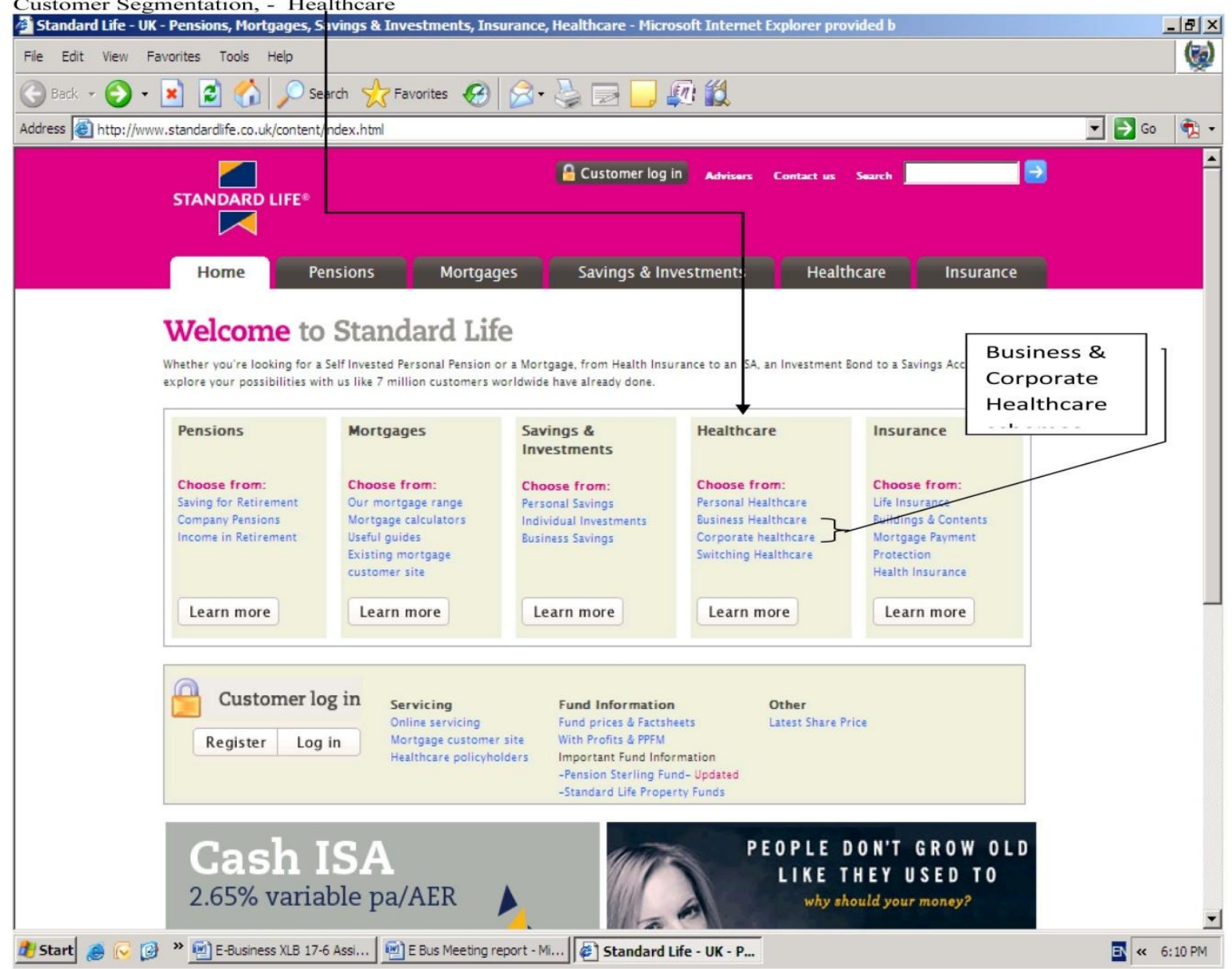


Appendix 5.
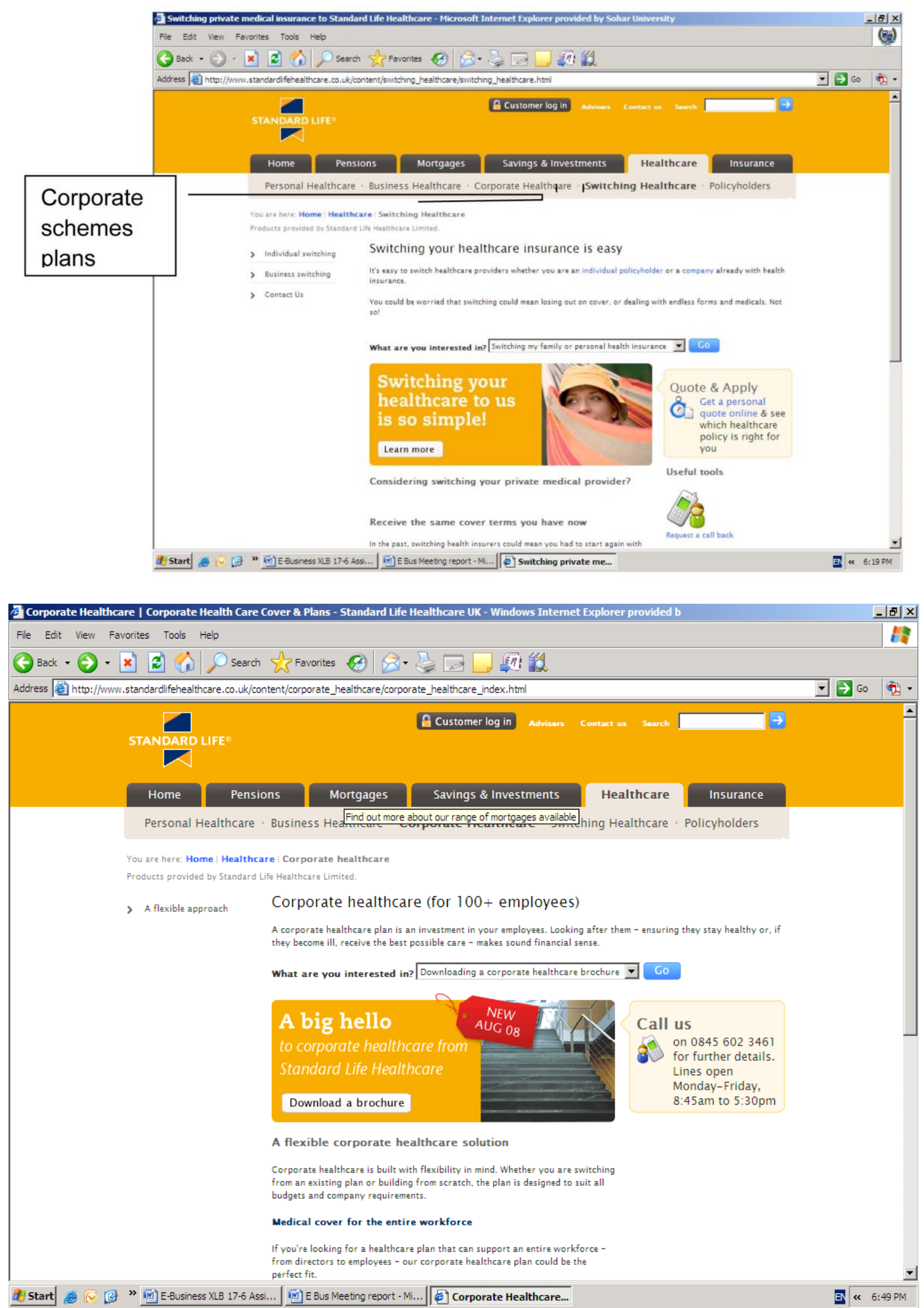


\section{Appendix 6. Home Page - William Russell}

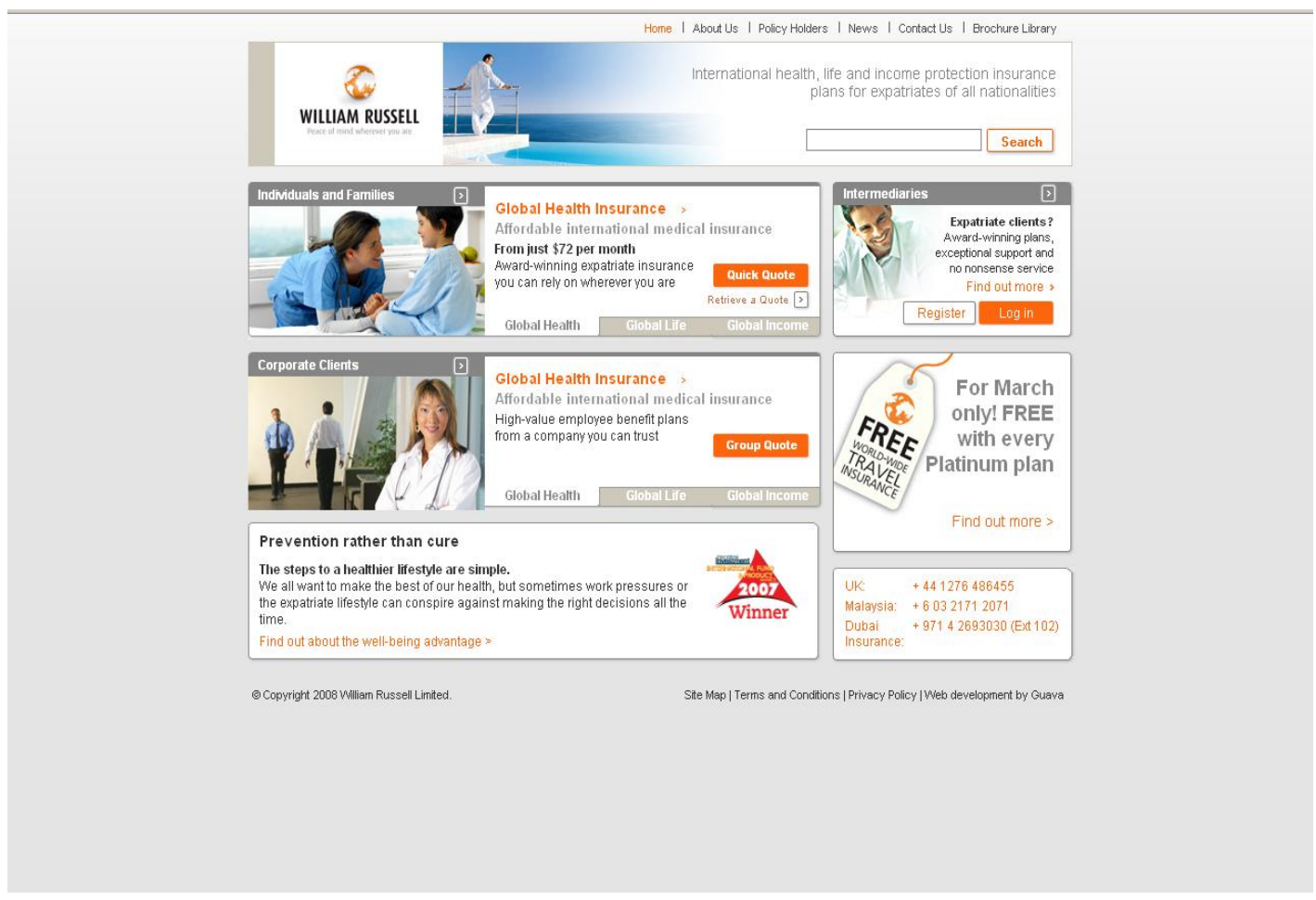

Ei International Health and Medical Insurance Cover for Expatriates | William Russell - Windows Internet Explorer provided by Soha

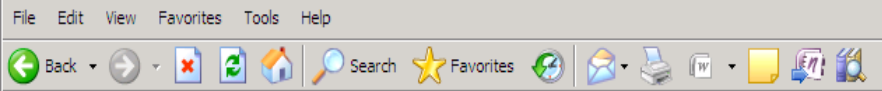

Address 9 http://www.william-russell, com/individualsandfamilies/global-health-insurance/

Address 10 http://WwW.Wiliam-russeli,com/individualsandfamilies/global-health-insurance/

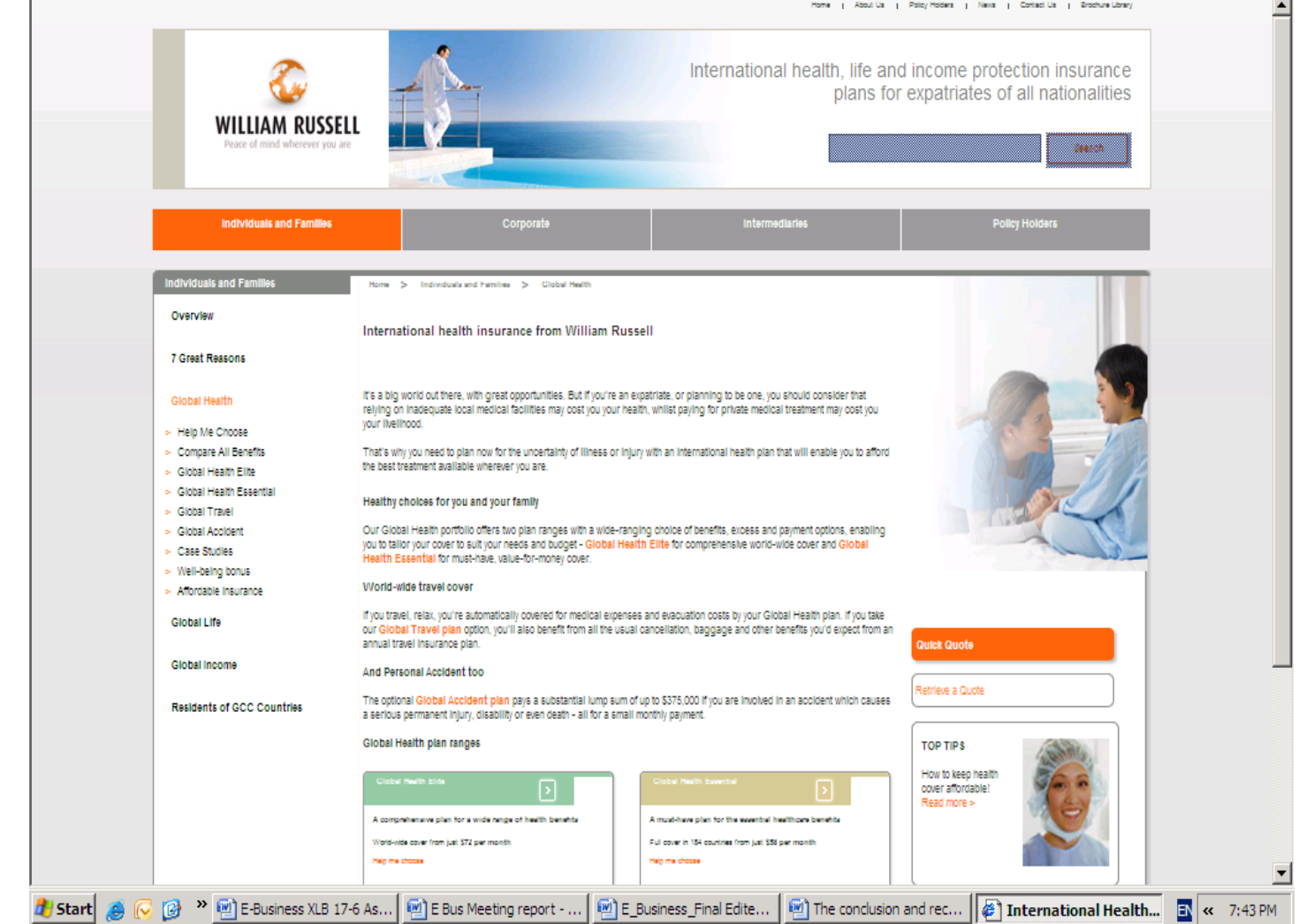


Appendix 7.

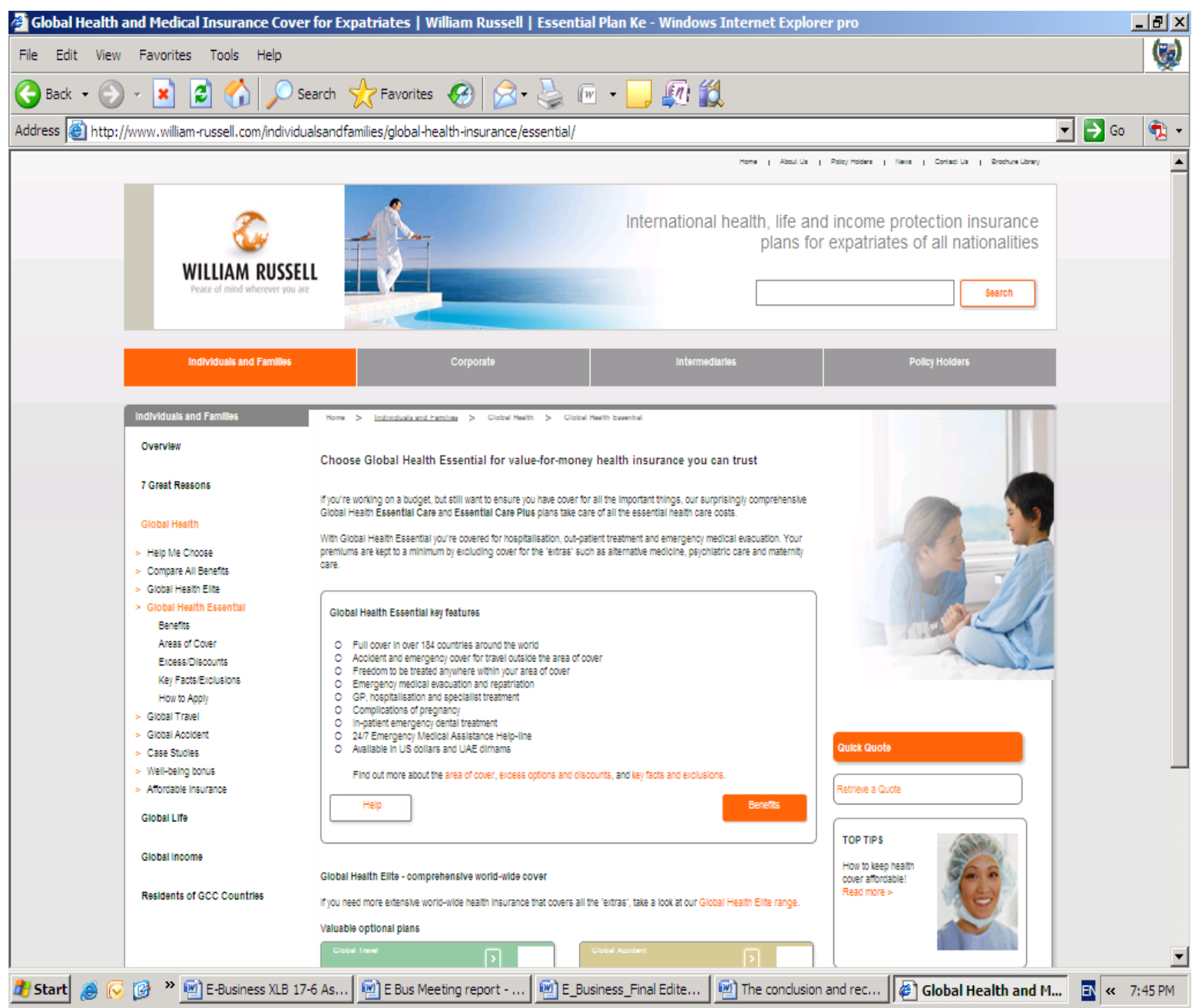

\section{Copyrights}

Copyright for this article is retained by the author(s), with first publication rights granted to the journal.

This is an open-access article distributed under the terms and conditions of the Creative Commons Attribution license (http://creativecommons.org/licenses/by/3.0/). 